\title{
Faktor-Faktor yang Berhubungan dengan Pneumonia Bakteri pada Anak
}

\author{
Ida Bagus Subanada, Ni Putu Siadi Purniti \\ Bagian/SMF Ilmu Kesehatan Anak FK Universitas Udayana/RSUP Sanglah Denpasar
}

\begin{abstract}
Latar belakang. Penyebab pneumonia penting dibedakan. Beberapa faktor yang dihubungkan dengan penyebab pneumonia adalah suhu, derajat pneumonia, gambaran foto dada, jumlah leukosit, dan kadar C-reactive protein (CRP).

Tujuan. Untuk mengetahui hubungan antara suhu, derajat pneumonia, gambaran foto radiologi dada, jumlah leukosit, dan CRP dengan pneumonia bakteri.

Metode. Penelitian retrospektif, dengan desain potong lintang, data didapat dari rekam medis pasien rawat inap dengan diagnosis pneumonia. Data yang diperoleh dilakukan analisis univariat dan multivariat dengan tingkat kemaknaan $\alpha=0,05$ (IK95\%).

Hasil. Derajat pneumonia tidak berhubungan dengan gambaran foto dada, dan kadar CRP; sedangkan suhu dan jumlah leukosit berhubungan dengan pneumonia bakteri RP 36,0 (IK 95\% 6,46;200,97), $p=<0,0001$ dan RP 4,2 (IK 95\% 1,39;12,88), $p=0,012$.

Kesimpulan. Suhu dan jumlah leukosit berhubungan dengan pneumonia bakteri.

Sari Pediatri 2010;12(3):184-9.
\end{abstract}

Kata kunci: suhu, derajat penyakit, foto dada, leukosit, CRP, pneumonia bakteri

$\mathrm{P}$ neumonia adalah inflamasi parenkim paru yang dihubungkan dengan konsolidasi ruang alveoli. ${ }^{1}$ Pneumonia ini masih merupakan masalah, baik dalam angka kesakitan maupun angka kematian. ${ }^{2}$ Insidens di negara berkembang sepuluh kali lebih tinggi dari pada negara maju dengan angka kematian pada balita sekitar 5 juta pertahun. ${ }^{3}$ Pada tahun 2005, di Indonesia didapatkan 600.720 kasus pneumonia pada balita dengan kematian 204

\section{Alamat korespondensi:}

Dr. Ida Bagus Subanada, Sp.A, Dr. Ni Putu Siadi Purniti, Sp.A. Divisi Respirologi, Bagian/SMF Ilmu Kesehatan Anak FK Unud/RSUP Sanglah Denpasar, E-mail: subanada@yahoo.com, HP: 08123995933 anak. ${ }^{4}$ Diagnosis dini serta pengobatan yang cepat akan menurunkan angka kematian. ${ }^{5}$

Penyebab pneumonia beragam dengan dua penyebab terbanyak adalah virus dan bakteri. ${ }^{6-9}$ Berkaitan dengan pemberian antimikroba, sangatlah penting untuk membedakan pneumonia bakteri dengan pneumonia virus. ${ }^{10}$ Biakan bakteri memerlukan waktu beberapa hari serta tidak tersedia di semua tempat. Oleh karena itu diperlukan parameter lain yang dapat digunakan. Beberapa penelitian melaporkan bahwa pneumonia oleh karena bakteri umumnya memberi gambaran klinis yang lebih toksik, ${ }^{6,9}$ suhu lebih tinggi, ${ }^{6,11}$ adanya gambaran konsolidasi atau efusi pleura pada foto dada, ${ }^{12,13}$ leukositosis dengan dominasi polimorfonuklear, ${ }^{9,14,15}$ dan kadar $C$-reactive 
protein (CRP) yang lebih tinggi. ${ }^{9}{ }^{14}$ Hasil penelitian tersebut tidak konsisten dengan hasil penelitian lainnya. $5,12,14,16,17$ Atas dasar hal tersebut dilakukanlah penelitian dengan tujuan untuk mengetahui hubungan antara suhu, derajat penyakit pneumonia, foto dada, jumlah leukosit, dan kadar CRP dengan pneumonia bakteri.

\section{Metode}

Penelitian retrospektif, dengan desain potong lintang, analitik, dilakukan di Divisi Respirologi, Bagian/SMF Ilmu Kesehatan Anak FK UNUD/RSUP Sanglah Denpasar. Subyek diambil secara consecutive sampling dari rekam medis pasien rawat inap, sejak bulan Desember 2007 sampai November 2008 dengan kriteria inklusi yaitu pasien pneumonia yang berusia $\geq 2$ bulan. Subjek akan dieksklusi bila data yang dicari tidak lengkap atau menderita penyakit lain selain pneumonia.

Diagnosis pneumonia ditegakkan secara klinis berdasarkan kriteria organisasi kesehatan sedunia WHO (World Health Organization) yaitu ditemukan adanya batuk atau sesak napas dan takipne serta pada auskultasi terdengar ronki, suara napas menurun atau suara napas bronkial. Subjek dikelompokkan pneumonia berat bila selain temuan yang telah disebutkan juga ditemukan salah satu dari gejala, retraksi, merintih, atau napas cuping hidung. Sedangkan pneumonia sangat berat bila selain gejala/ tanda pneumonia berat juga ditemukan salah satu dari gejala, sianosis sentral, tidak bisa minum, muntah, kejang, letargi, kesadaran menurun atau anggukan kepala. Data didapat dari rekam medis antara lain usia, jenis kelamin, status gizi, pemakaian antimikroba sebelum rawat inap, pemakaian antipiretik sebelum rawat inap, lama sakit sebelum rawat inap, riwayat imunisasi Hib dan/atau pneumokokus, suhu, derajat pneumonia, foto dada, jumlah leukosit, kadar CRP, dan hasil biakan darah serta hasil tes sensitivitas. Jumlah leukosit dibagi menjadi $\leq 15.000 \times 10^{\circ} / \mathrm{L}$ dan $>15.000$ x $10^{9} / \mathrm{L}$, sedangkan jumlah CRP dikelompokkan menjadi $\leq 80 \mathrm{mg} / \mathrm{L}$ dan $>80 \mathrm{mg} / \mathrm{L}$. Foto dada dibaca ulang oleh peneliti, berdasarkan kriteria WHO untuk memperkirakan penyebab pneumonia. Adanya infiltrat lobar atau infiltrat alveoli dengan diameter $>2,5 \mathrm{~cm}$ atau infiltrasi pleura diklasifikasikan sebagai penyebab bakteri, sedangkan infiltrasi lainnya diklasifikasikan sebagai penyebab virus. ${ }^{13}$ Sebelum dibaca, foto dada diisi nomor secara acak oleh asisten peneliti, identitas subjek ditempeli kertas sehingga peneliti tidak mengetahui identitas subjek. Pengukuran suhu dilakukan pada aksila dengan termometer air raksa, dikelompokkan menjadi suhu $<39^{\circ} \mathrm{C}$ dan suhu $\geq 39^{\circ} \mathrm{C}$. Subjek dimasukkan kelompok pneumonia bakteri bila hasil biakan darah ditemukan mikroba, sedangkan bila tidak ditemukan mikroba dimasukkan kelompok pneumonia non-bakteri. Besar sampel dihitung berdasarkan rule of thumb terhadap lima variabel yang diteliti sehingga total diperlukan 50 sampel per kelompok. Nilai $\mathrm{p}<0,05$ (IK 95\%) berarti bermakna secara statistik.

Data dengan skala katagorikal akan dianalisis dengan uji kai-kuadrat atau alternatifnya. Analisis multivariat (regresi logistik) dilakukan untuk menguji beberapa variabel yang diduga berhubungan dengan pneumonia bakteri. Penelitian telah mendapatkan ijin kelaikan etik dari Komite Etik Penelitian FK Unud/ RSUP Sanglah Denpasar.

\section{Hasil}

Selama periode penelitian didapat 128 subjek yang memenuhi kriteria inklusi, 28 subjek dieksklusi antara lain karena data yang dicari tidak lengkap (3 orang), menderita penyakit lain selain pneumonia (8 orang), dan 17 orang karena gabungan kedua penyebab di atas. Bakteri penyebab pneumonia antara lain Staphylococcus coagulase positif 34\%, Staphylococcus ludgunensis $18 \%$, Staphylococcus hominis dan Staphylococcus intermedius masing-masing $8 \%$, Staphylococcus albus dan Flavimonas oryzihabitans masing-masing 4\%, Eschericia coli, Staphylococcus xylosus, Staphylococcus capitis, Staphylococcus aureus, Staphylococcus mitis, Acinetobacter baumani, Klebsiela pneumoniae, Staphylococcus sciuri, Staphylococcus chromogenes, Streptococcus haemoliticus, Staphylocus cohni, Pseudomanona sp. masing masing $2 \%$. Median usia subjek 8 bulan (usia minimum 2 bulan dan maksimum 60 bulan), jenis kelamin laki-laki $60 \%$, keadaan malnutrisi 4\%, memakai antimikroba sebelum rawat inap 65\%, pemakaian antipiretik sebelum rawat inap $85 \%$, dan semuanya belum pernah mendapat imunisasi Hib ataupun pneumokokus. Karakteristik subjek pada kedua kelompok tertera pada Tabel 1, dan terlihat tidak ada perbedaan yang mencolok antara kedua kelompok. 
Ida Bagus Subanada dkk: Faktor-faktor yang berhubungan dengan pneumonia bakteri pada anak

Tabel 1. Karakteristik subjek

\begin{tabular}{lcc}
\hline Karakteristik & $\begin{array}{c}\text { Pneumonia bakteri } \\
(\mathrm{N}=50)\end{array}$ & $\begin{array}{c}\text { Pneumonia non- } \\
\text { bakteri }(\mathrm{N}=50)\end{array}$ \\
\hline Usia, bulan, rerata (SE) & $10,6(1,60)$ & $11,6(1,59)$ \\
Jenis kelamin laki, n (\%) & $32(64)$ & $28(56)$ \\
Malnutrisi, n (\%) & $1(2)$ & $3(6)$ \\
Minum antimikroba sebelum rawat inap, n (\%) & $30(60)$ & $35(70)$ \\
Minum antipiretik sebelum rawat inap, n (\%) & $40(80)$ & $45(90)$ \\
Lama sakit sebelum rawat inap, hari, rerata (SB) & $3,9(0,69)$ & $3,7(0,72)$ \\
Imunisasi Hib atau pneumokokus, n (\%) & $50(100)$ & $50(100)$ \\
\hline
\end{tabular}

$\mathrm{SE}=$ standard error

Tabel 2. Analisis bivariat beberapa variabel yang diduga berhubungan dengan pneumonia bakteri

\begin{tabular}{lcccc}
\hline Variabel & Pn. bakteri & Pn. non-bakteri & RP (IK 95\%) & p \\
\hline - Suhu $\geq 39^{\circ} \mathrm{C}$ sesaat sebelum pengambilan & & & & \\
$\quad$ sampel darah, n (\%) & $47(94)$ & $19(38)$ & $25,6(6,97 ; 93,73)$ & $<0,0001$ \\
- Pneumonia sangat berat, n (\%) & $33(66)$ & $16(32)$ & $4,1(1,79 ; 9,50)$ & 0,001 \\
- Foto dada ada konsolidasi dan/ atau efusi & & & & \\
$\quad$ pleura, n (\%) & $11(22)$ & $4(8)$ & $3,2(0,96 ; 11,00)$ & 0,05 \\
- Leukosit $>5 \times 109 / \mathrm{L}, \mathrm{n}(\%)$ & $36(72)$ & $19(38)$ & $4,2(1,81 ; 9,73)$ & 0,001 \\
- CRP $>80 \mathrm{mg} / \mathrm{L}, \mathrm{n}(\%)$ & $36(72)$ & $17(34)$ & $5,0(2,13 ; 11,63)$ & 0,0001 \\
\hline
\end{tabular}

Tabel 3. Analisis regresi logistik beberapa variabel yang diduga berhubungan dengan pneumonia bakteri

\begin{tabular}{lccc}
\hline Variabel & RP & IK 95\% & p \\
\hline Suhu $\geq 39^{\circ} \mathrm{C}$ sesaat sebelum pengambilan sampel darah & 36,0 & 6,$46 ; 200,97$ & $<0,0001$ \\
Pneumonia sangat berat & 2,3 & 0,$46 ; 11,76$ & 0,304 \\
Foto dada ada konsolidasi dan/atau efusi pleura & 4,0 & 0,$59 ; 26,59$ & 0,154 \\
Leukosit $>15 \times 109 / \mathrm{L}$ & 4,2 & 1,$39 ; 12,88$ & 0,012 \\
$\mathrm{CRP}>80 \mathrm{mg} / \mathrm{L}$ & 1,5 & 0,$29 ; 7,61$ & 0,633 \\
\hline
\end{tabular}

Pada analisis bivariat (Tabel 2) didapatkan suhu $\geq 39^{\circ} \mathrm{C}$, derajat pneumonia, jumlah leukosit $>15 \times 10^{9} / \mathrm{L}$, CRP $>80 \mathrm{mg} / \mathrm{dL}$ berhubungan bermakna, sedangkan foto dada berhubungan dengan kejadian pneumonia, namun tidak bermakna secara statistic $(\mathrm{p}=0,05)$.

Pada analisis multivariat, didapatkan hasil bahwa suhu $\geq 39^{\circ} \mathrm{C}$ dan jumlah leukosit $>15 \times 10^{\circ} / \mathrm{L}$ berhubungan bermakna dengan pneumonia bakteri (Tabel 3).

\section{Pembahasan}

Pneumonia banyak mengenai usia balita, ${ }^{2}$ anak dengan malnutrisi, ${ }^{18,19}$ dan jenis kelamin laki-laki. ${ }^{5,19}$ Pada penelitian kami didapatkan median usia pasien pneumonia adalah 8 bulan (usia minimum 2 bulan dan maksimum 60 bulan), malnutrisi $4 \%$, serta laki-laki $60 \%$.
Kejadian bakteremia pada pneumonia berkisar antara 10\%-25\%. Biakan darah lebih sering positif pada pasien dengan suhu di atas $39^{\circ} \mathrm{C}$ dan foto dada konsisten dengan penyakit bakteri. ${ }^{6}$ Penelitian kami mendapatkan suhu $\geq 39^{\circ} \mathrm{C}$ sesaat sebelum pengambilan sampel darah berhubungan dengan bakteremia [RP 36,0 (IK 95\% 6,46;200,97)]. Tiga peneliti sebelumnya antara lain mendapatkan hasil bahwa suhu tubuh merupakan indikator yang jelek dari infeksi bakteri pada pneumonia aspirasi, ${ }^{16}$ tidak ada perbedaan suhu antara pneumonia oleh karena bakteri dan virus. ${ }^{5,14}$ Perbedaan hasil tersebut antara lain karena suhu tubuh yang dipakai pada pneumonia aspirasi adalah suhu tubuh dalam 24 jam pertama rawat inap, ${ }^{16}$ sedangkan peneliti lain memakai pengukuran suhu rektal pada subjek usia $<3$ tahun dan suhu aksila pada subjek usia $\geq 3$ tahun, serta tidak menyebut jumlah subjek yang diukur per-rektal pada masing-masing kelompok. ${ }^{14}$ 
Satu peneliti memakai pengukuran suhu oral, aksila, dan rektal, serta menentukan penyebab pneumonia berdasarkan foto dada menurut kriteria WHO. ${ }^{5}$

Bakteremia menandakan kemungkinan besar bakteri tersebut sebagai penyebab pneumonia. Bakteri penyebab pneumonia antara lain Streptococcus pneumoniae, Haemofilus influenza type b, Staphylococcus aureus, Moraxella catharalis, Klebsiela pneumoniae, Mycoplasma pneumoniae, Chlamydia pneumoniae, dan Chlamydia trachomatis. ${ }^{12,18,20}$ Penelitian kami mendapatkan mikroba Staphylococcus koagulase positif sebagai penyebab terbanyak, kemudian diikuti Staphylococcus ludgunensis, Staphylococcus hominis dan Staphylococcus intermedius, serta Flavimonas oryzihabitans dan Staphylococcus albus.

Pneumonia bakteri umumnya memberi gambaran klinis yang lebih toksik dari pneumonia virus. ${ }^{6,9}$ Penelitian kami tidak mendapatkan adanya hubungan antara derajat pneumonia dengan penyebab pneumonia. Hal tersebut mungkin karena tidak dilakukan biakan lain selain biakan bakteri (termasuk bakteri anaerob) sehingga adanya infeksi campuran yang umumnya memberikan gejala lebih berat tidak diketahui.Menurut WHO, gambaran foto dada yang khas pneumonia bakteri adalah adanya gambaran konsolidasi lobar atau infiltrat alveolar dengan diameter $>2,5 \mathrm{~mm}$, atau adanya infiltrasi pleura (efusi pleura). ${ }^{13}$ Penelitian kami mendapatkan gambaran foto rontgen dada tidak berhubungan dengan pneumonia bakteri. Peneliti lain mendapatkan penyebab bakteri pada $71 \%$ dari 137 anak dengan infiltrat alveolar pada foto dada, sementara $72 \%$ dari 134 kasus pneumonia bakteri mempunyai infiltrat alveolar. Setengah dari 77 anak dengan infiltrat interstisial mempunyai bukti adanya infeksi bakteri. ${ }^{12}$ Ada pula yang mendapatkan pneumonia lobar pada 16\% pneumonia virus dan 59\% pneumonia bakteri, sedangkan adanya infiltrat alveolar tidak berbeda antara pneumonia bakteri (61\%) dengan virus $(69 \%) .{ }^{14}$ Perbedaan hasil ini karena perbedaan dalam menentukan penyebab pneumonia. Dilaporkan pada penelitian sebelumnya memakai pemeriksaan antibodi bakteri pada fase akut dan konvalesen, ${ }^{12}$ ada pula dengan mencari penyebab bakteri anaerob dan penyebab lain selain bakteri sehingga adanya infeksi campuran dapat diketahui. ${ }^{14}$

Apabila bakteri diduga sebagai penyebab pneumonia, pada umumnya dijumpai leukositosis dengan dominasi sel polimorfonuklar, sedangkan bila penyebabnya virus, didominasi oleh sel limfosit. ${ }^{9}$
Penelitian kami mendapatkan kadar leukosit $>15,0 \times 10^{9} / \mathrm{L}$ lebih banyak pada penyebab bakteri (72\%) dibanding penyebab non-bakteri (38\%). Hasil tersebut sesuai dengan dua penelitian sebelumnya yang melaporkan bahwa kadar leukosit $\left(>15 \times 10^{9} / \mathrm{L}\right)$ lebih tinggi pada pneumonia bakteri (74\%) dibanding pneumonia virus $(50 \%),{ }^{14}$ dan $72 \%$ pasien yang dicurigai pneumonia bakteri secara klinis dan foto dada, serta tidak diobati, mengalami peningkatan leukosit $\left(15.000 / \mathrm{mm}^{3}\right)$ pada hari sakit kedua. ${ }^{15}$ Sebaliknya dengan tiga penelitian lain sebelumnya, $, 12,16$ mungkin karena perbedaan cara menentukan penyebab pneumonia. Satu peneliti menentukan penyebab pneumonia seperti yang telah diterangkan (WHO), ${ }^{12}$ peneliti lainnya menentukan penyebab pneumonia berdasarkan hasil yang diperoleh dari bronkoskopi, ${ }^{16}$ sedangkan peneliti terakhir menentukan penyebab pneumonia berdasarkan foto dada. ${ }^{5}$ Sebuah penelitian yang menggunakan variabel suhu aksila, usia, jumlah neutrofil, jumlah batang, dan foto dada, dengan memakai sistem skor mendapatkan bahwa nilai skor $\geq 4$ mempunyai sensitivitas $100 \%$, spesifisitas $93,8 \%$, nilai duga positif $75,8 \%$, dan nilai duga negatif $100 \%$ dalam memprediksi pneumonia bakteri. ${ }^{10}$

C-reactive protein merupakan salah satu protein fase akut non-spesifik yang dihasilkan hati, kadar dalam darah meningkat pada inflamasi sebagai akibat respons imun non-spesifik. Pada infeksi bakteri kadar CRP umumnya meningkat. ${ }^{18} \mathrm{Hal}$ ini terjadi karena bakteri pada umumnya menyebabkan penyakit yang lebih berat akibat inflamasi yang lebih luas sehingga lebih banyak melepaskan sitokin IL-6 yang merupakan sitokin penginduksi sintesis CRP. ${ }^{6}$ Pada penelitian kami tidak didapatkan hubungan antara pneumonia bakteri dengan kadar CRP. Hasil tersebut sesuai dengan systematic review yang melaporkan bahwa CRP tidak cukup sensitif dan tidak cukup spesifik dalam menentukan bakteri sebagai penyebab infeksi respiratorik bawah. ${ }^{17}$ Adnet $^{16}$ melaporkan bahwa pengukuran awal CRP berguna untuk mendiagnosis adanya infeksi bakteri aerob pada pneumonia aspirasi dengan rerata CRP 169,8 (SB 106,4) mg/L pada biakan bakteri positif dibanding 42,9 (SB 40,1) mg/L pada biakan bakteri negatif, sedangkan peneliti lainnya melaporkan kadar CRP $>80 \mathrm{mg} / \mathrm{L}$ lebih banyak pada pneumonia bakteri (72\%) dibanding pneumonia virus (34\%). ${ }^{14}$ Perbedaan tersebut kemungkinan karena pada satu penelitian dilakukan juga biakan selain biakan bakteri, ${ }^{14}$ sedangkan pada penelitian ini biakan 
Ida Bagus Subanada dkk: Faktor-faktor yang berhubungan dengan pneumonia bakteri pada anak

tersebut tidak dilakukan (termasuk biakan untuk kuman anaerob) sehingga adanya infeksi campuran pada kedua kelompok tidak dapat disingkirkan. Pada penelitian lainnya mungkin karena penyakit dasarnya adalah pneumonia aspirasi sehingga inflamasi telah terjadi sebelum terinfeksi oleh bakteri. ${ }^{16}$

Keterbatasan penelitian kami antara lain penentuan penyebab pneumonia berdasarkan biakan darah karena kejadian bakteremia pada pneumonia relatif rendah sehingga hasil negatif tidak menutup kemungkinan bakteri sebagai penyebab, tidak dilakukan pemeriksaan/biakan lain selain bakteri sehingga kemungkinan penyebab campuran tidak tersingkirkan, pengukuran suhu dilakukan saat tiba di rumah sakit (suhu lebih tinggi mungkin terjadi saat sebelum dirawat di rumah sakit), waktu antara minum antipiretik dengan pengukuran suhu tidak diketahui, serta terakhir adalah penggunaan rule of thumb untuk menghitung besar sampel. Disimpulkan bahwa suhu $\geq 39^{\circ} \mathrm{C}$ dan kadar leukosit $>15,0 \times 10^{\%} / \mathrm{L}$ berhubungan dengan pneumonia bakteri. Diperlukan penelitian lebih lanjut dengan desain yang lebih baik untuk mengetahui konsistensi hasil penelitian ini.

\section{Daftar pustaka}

1. Behrman RE, Kliegman RM. Nelson Essentials of Pediatrics. Edisi ke 4. Philadelphia: Saunders; 2002.h.541-3.

2. Bryce J, Boschi-Pinto C, Shibuya K, Black RE. WHO child health epidemiology reference group. WHO estimates of the causes of the death in children. Lancet 2005;365:1147-52.

3. William JD, Christopher S. Pneumonia. Pediatr Rev 2008;29:147-60.

4. Departemen Kesehatan Republik Indonesia. Profil Kesehatan Indonesia 2005. Jakarta: Departemen Kesehatan; 2007.

5. Muangchana C. Factors associated with diagnosis of bacterial pneumonia in children of Northern Thailand. Southeast Asian J Trop Med Public Health 2009;40:563-9.

6. Berman S, Eichner JM. Pneumonia. Dalam: Berman S, penyunting. Pediatric Decision Making. Edisi ke-4. Philadelphia: Mosby; 2003.h.758-63.

7. Crowe JE. Viral pneumonia. Dalam: Chernick V, Boat TF, Wilmott RW, Bush A, penyunting. Kendig's
Disorder of the Respiratory Tract in Children. Edisi ke-7. Philadelphia: Saunders; 2006.h.433-40.

8. Stein RT, Marostica PJC. Community-acquired bacterial pneumonia. Dalam: Chernick V, Boat TF, Wilmott RW, Bush A, penyunting. Kendig's Disorder of the Respiratory Tract in Children. Edisi ke-7. Philadelphia: Saunders; 2006.h.441-52.

9. Said M. Pneumonia. Dalam: Rahajoe NN, Supriyatno B, Setyanto DB, penyunting. Buku Ajar Respirologi Anak. Edisi ke-1. Jakarta: BP IDAI; 2008.h.350-65.

10. Moreno L, Krishnan JA, Duran P, Ferrero F. Development and validation of a clinical prediction rule to distinguish bacterial from viral pneumonia in children. Pediatr Pulmonol 2006;41:331-7.

11. Banya WA, Q'Demsey TJ, McArdle T, Lloyd-Evans N, Greenwood BM. Predictors for a positive blood culture in African children with pneumonia. Pediatr Infect Dis J 1996;15:292-7.

12. Virki R, Juven T, Rikalainen H, Svedstrom E, Mertsola J, Ruuskanen O. Differentiation of bacterial and viral pneumonia in children. Thorax 2002;57:438-41.

13. Cherian T, Mulholland EK, Carlin JB, Ostensen H, Amin R, de Campo M, dkk. Standardized interpretation of paediatric chest radiograph for the diagnosis of pneumonia in epidemiological studies. Bull World Health Organ 2005;83:353-9.

14. Juven T, Mertsola J, Waris M, Leinonen M, Ruuskanen O. Clinical responses to antibiotic therapy for communityacquired pneumonia. Eur J Pediatr 2004;163:140-4.

15. Triga MG, Syrogiannopoulos GA, Thoma KD, Fezoulidis IB, Pastromas VG, Beratis NG. Correlation of leucocyte count and erythrocyte sedimentation rate with the day of illness in presumed bacterial pneumonia of childhood. J Infect 1998;36:63-6.

16. Adnet F, Borron SW, Vicant E, Giraudeaux V, Lapostolle F, Bekka R, dkk. Value of c-reactive protein in the detection of bacterial contamination at the time of presentation in drug-induced aspiration pneumonia. Chest 1997;112:466-71.

17. van der Meer V, Neven AK, van den Broek PJ, Assendelft WJJ. Diagnostic value of C-reactive protein in infections of the lower respiratory tract: systematic review. BMJ. 2005;331:26(2 July) (diakses tanggal 5 Juli 2010). Diunduh dari:http://www.bmj.com/cgi/content/ full/331/7507/26

18. Woods CR. Acute bacterial pneumonia in childhood in the currrent era. Pediatric ann 2008:37:694-02.

19. Johnson Abdul-Wahab BR, Osinusi K, Aderele WI, Gbadero DA, Olaleye OD, Adeyemi-Doro FAB. Etiologic 
Ida Bagus Subanada dkk: Faktor-faktor yang berhubungan dengan pneumonia bakteri pada anak

agents and outcome determinats of community-acquired pneumonia in urban children: a hospital-based study. JNMA 2008;100:370-85.
20. Ostapchuk M, Roberts DM, Haddy R. Communityacquired pneumonia in infants and children. Am Fam Physician 2004;70:899-908. 